\title{
Within-session observations of rats leverpressing in the presence of free food
}

\author{
DONALD E. JACKSON \\ Eastern Michigan University, Ypsilanti, Michigan 48197
}

\begin{abstract}
Rats trained to leverpress on a continuous reinforcement schedule for food pellets were observed during a 40-min choice session during which pellets could be obtained freely from a cup or by leverpressing. All rats initially ate from the cup but alternated a mean of 16 times between pellet sources, earning a mean of $52 \%$ of the pellets consumed. The rats earned food during a mean of 13 of the 20 possible 2-min intervals and took pellets freely during a mean of 12 intervals. There were both more alternations and more leverpresses during the first half of the session.
\end{abstract}

That animals will respond for food while in the presence of freely available identical food is well documented. Variables which have been manipulated include amount of operant experience before choice testing (Jensen, 1963), method of free-food presentation (Hothersall, Huey, \& Thatcher, 1973), reinforcement schedule (Atnip \& Hothersall, 1973; Tarte \& Vernon, 1974), and level of food deprivation (Tarte \& Snyder, 1972).

A commonly used index of what has become known as "contrafreeloading" is the percentage of total food consumed on choice day that was earned. Using $50 \%$ as a reference, subjects either prefer to earn their food (or other reinforcer) or to freeload. In fact, so much attention has been paid to this single aspect of the organism's behavior that little information exists regarding initial preferences, within-session alternations, etc. Such observations would indicate whether an organism settles on one source of food or shifts from one to another during the session.

The purpose of the present study, then, was to systematically observe rats on choice day to determine initial source of food, latency before first alternation, and number of alternations. Tarte, Townsend, and Vernon (1973) found that rats raised in an "enriched" environment tended to work less than control subjects. While this result was the opposite of what had been predicted, it suggests that housing conditions may be a determiner of the phenomenon. Therefore, half the subjects in the present study were given "enriched" home cages.

\section{METHOD}

\section{Subjects}

Ten naive male albino rats (Sprague-Dawley) obtained from Spartan Research Animals, Haslett, Michigan, served as subjects. The rats were individually housed in standard laboratory cages under constant illumination with unlimited access to water.

Requests for reprints should be sent to Donald E. Jackson, Department of Psychology, Eastern Michigan University, Ypsilanti, Michigan 48197. This paper is sponsored by Dennis J. Delprato, who takes full editorial responsibility for its contents.
Restricted feeding of Purina Rat Chow maintained the rats at $90 \%$ of their free-feeding weight (mean $=297 \mathrm{~g}$, range 297-335 g).

\section{Apparatus}

Ten identical Lehigh Valley dual-lever chambers (right lever permanently retracted) were used. Each chamber $(30.5 \times 24 \times$ $27 \mathrm{~cm}$ ) was housed in a blower-ventilated enclosure located in one of 10 separate cubicles. Observers watched the rats through a glass panel in the cubicle door. Metal cups $(3 \mathrm{~cm}$ deep $\times 5 \mathrm{~cm}$ in diam) were used for free-food presentations. Blocks of wood $(10 \times 5 \times 2 \mathrm{~cm}$ ) and crumpled brown wrapping paper $(30 \times 50 \mathrm{~cm})$ were placed in half the home cages. Digital counters located in an adjacent room recorded leverpresses.

\section{Procedure}

The rats were food deprived and allowed to self-train for $45-\mathrm{mg}$ Noyes pellets to a criterion of 70 responses on a continuous reinforcement schedule (CRF). The wood blocks and paper were placed in a randomly selected half of the cages on this day (paper was replaced daily with fresh paper). Eight training days followed, during which each rat earned 70 daily reinforcements on the CRF schedule. Prior to Training Day 2, each rat received 50 free pellets in the metal cup (all rats ate all pellets within $7 \mathrm{~min}$ ). The response lever was retracted and the cup anchored in the corner diagonally across from the retracted response lever. Choice testing followed the 8th training day. The metal cup containing 300 pellets was in place, the response lever was extended, and the rat was placed into the chamber facing the neutral rear corner, approximately equidistant from the foodcup and the response lever. During the next $40 \mathrm{~min}$, the rats were observed and cumulative responses recorded. The following observations were made: (a) source of the first pellet (cup or response produced), (b) time interval that the rat remained at the initial source of pellets before alternating, (c) whether, during a given minute, the rat obtained free food (yes or no), (d) whether, during a given minute, the rat obtained earned food (yes or no), and (e) the number of times that the rat alternated from one source of pellets to the other.

\section{RESULTS AND DISCUSSION}

Table 1 summarizes the observations made during the 40-min choice session. Rank tests were run to compare the rats that had the paper and wood (E rats ) with those that did not (C rats). No significant differences were found in any of the following comparisons: total pellets consumed, percentage of pellets consumed which were earned, number of seconds before first alternation, number of times alternated, number of 2-min intervals 
Table 1

Summary of Observations Made During the 40-Min Choice Session

\begin{tabular}{|c|c|c|c|c|c|c|c|c|c|}
\hline \multirow[b]{2}{*}{ Rat } & \multicolumn{2}{|c|}{$\begin{array}{c}\text { Number of } \\
\text { Pellets }\end{array}$} & \multirow{2}{*}{$\begin{array}{l}\text { Percent } \\
\text { Earned }\end{array}$} & \multirow{2}{*}{$\begin{array}{c}\text { Seconds } \\
\text { Before } \\
\text { First } \\
\text { Alternation }^{\mathrm{a}}\end{array}$} & \multirow{2}{*}{$\begin{array}{c}\text { Times } \\
\text { Alternated }\end{array}$} & \multirow{2}{*}{$\begin{array}{c}\text { Alternations } \\
\text { First } \\
20 \mathrm{Min} \\
\end{array}$} & \multirow{2}{*}{$\begin{array}{c}\text { Percent } \\
\text { Responses } \\
\text { First } \\
20 \mathrm{Min} \\
\end{array}$} & \multicolumn{2}{|c|}{$\begin{array}{c}\text { Number of } \\
\text { 2-Min } \\
\text { Intervals } \\
\text { Pellets Obtained } \\
\end{array}$} \\
\hline & From Cup & Earned & & & & & & Free & Earned \\
\hline$E-1^{b}$ & 56 & 148 & 73 & 22 & 12 & 9 & 68 & 10 & 14 \\
\hline $\mathrm{E}-2$ & 80 & 155 & 66 & 30 & 13 & 13 & 51 & 6 & 11 \\
\hline E-3 & 34 & 192 & 85 & 55 & 21 & 11 & 59 & 11 & 16 \\
\hline E-4 & 150 & 153 & 50 & 195 & 12 & 9 & 51 & 12 & 15 \\
\hline E-5 & 123 & 155 & 56 & 20 & 23 & 14 & 72 & 16 & 16 \\
\hline$C-1$ & 206 & 39 & 16 & 240 & 13 & 10 & 46 & 18 & 8 \\
\hline C-2 & 63 & 161 & 72 & 45 & 9 & 5 & 62 & 6 & 18 \\
\hline C-3 & 179 & 55 & 24 & 135 & 9 & 5 & 95 & 13 & 6 \\
\hline$C-4$ & 191 & 50 & 21 & 145 & 21 & 9 & 63 & 18 & 11 \\
\hline$C-5$ & 77 & 109 & 59 & 70 & 26 & 17 & 64 & 13 & 15 \\
\hline Means & 116 & 122 & 52 & 96 & 16 & 10 & 63 & 12 & 13 \\
\hline
\end{tabular}

during which pellets were taken freely, and number of 2-min intervals during which pellets were earned. All 10 rats initially went to the free-food cup, 9 of 10 alternated more during the first $20 \mathrm{~min}$, and 9 of 10 responded more in the first $20 \mathrm{~min}$ of the session (all ps $<.05$ for a two-tailed sign test). There was no systematic tendency for the rats to spend more time at either source of pellets as the session progressed. The number of 2-min intervals during which the rats obtained food freely, or by working, decreased at the same rate between the first and last half of the session (means decreased from 6.6 to 5.7 for free food and from 7.0 to 6.0 for earned food).

The percentage of pellets consumed which were earned (mean $=52$ ) agrees with prior studies which used CRF schedules and approximately the same amount of prior training (Jensen, 1963; Taylor, 1972). However, the observations made in the present study disagree with the nonsystematic impressions of others. Jensen (1963) reported it was his impression that, once a rat started pressing, he did not return to the free-food cup. The present study indicated that the rats alternated from one source of pellets to another a mean of 16 times during the 40-min session (the same duration used by Jensen).

Nor did the observations of the present study agree with those reported by Atnip and Hothersall (1973). Their procedure involved placing the free-food cup into the chamber after 25 responses had occurred; those rats that preferred free food waited for "a long period of time" before resuming leverpressing, but once resumed, leverpressing continued until the end of the session. For those rats that preferred earned food, leverpressing resumed after a "relatively short latency" (p. 154). Was the lack of alternation reported by Jensen and Atnip and Hothersall due to the interruption procedure which each used?
Like many studies, the present study found that some rats prefer free food and some prefer earned food (range of percentage of consumed food earned was 16-85). In addition, the present study indicates that rats, regardless of computed preference, alternated many times between the two sources of pellets, despite the fact that all subjects initially went to the free-food cup. The phenomenon of working in the presence of free food is obviously very easy to demonstrate in rats. Is this tendency a natural consequence of the rats living under conditions which restrict the opportunity to manipulate the environment? Kavanau (1967) has observed that animals in nature exercise a high degree of control over their environment. Under usual laboratory conditions, opportunities to interact with and modify the environment are considerably limited. Kavanau states that this frequently leads to the repetition of a behavior which manipulates the environment, even if this behavior appears inappropriate compared to the organism's behavior in nature. A discussion of this phenomenon is provided by Hediger (1964).

Would rats, then, be less inclined to work in the presence of freely available food if their housing arrangement provided more opportunity to interact with and modify their environment? This is what happened to rats that lived for 66 days in an enriched environment compared to controls housed two to the cage (Tarte, Townsend, \& Vernon, 1973). Enriched rats earned only $28.8 \%$ of the pellets consumed, while controls earned $76.2 \%$.

While a similar difference was not found in the present study, the paper and wood blocks were only available for manipulation for 8 days. Future research which manipulates the opportunity to interact with and control the environment will determine the extent to which this variable contributes to the phenomenon. 


\section{REFERENCES}

Atnip, G.. \& Hothersall, D. The preference of albino rats . for free or response-produced food. Bulletin of the Psychonomic Society. 1973, 2. 153-154.

Hediger. H. Wild animals in captivity. New York: Dover, 1964.

Hothersall, D., Huey, D.. \& Thatcher, K. The preference of rats for free or response-produced food. Animal Learning \& Behavior, 1973, 1, 242-243.

JENSEN, G. D. Preference for bar pressing over "freeloading" as a function of number of rewarded presses. Journal of Experimental Psychology, 1963. 65, 451-454.

Kavanau, J. L. Behavior of captive white-footed mice. Science, 1967. 155. 1623-1639.
TARTE, R. D.. \& SNYDER, R. L. Barpressing in the presence of free food as a function of food deprivation. Psychonomic Science, 1972, 26, 169-170.

TARTE, R. D.. \& Vernon, C. R. Rats' barpressing in the presence of free food as a function of fixed ratio schedules. Bulletin of the Psychonomic Society, 1974, 3, 34-36.

Tarte, R. D., Townsend, S. G., \& Vernon, C. R. Housing environment and the barpressing vs. freeloading phenomenon in rats. Bulletin of the Psychonomic Society. 1973. 2. 69-70.

TAYLOR. G. T. A limitation of the contrafreeloading phenomenon. Psychonomic Science, 1972, 29, 173-174.

(Received for publication June 5, 1976.) 